\section{Medalha de Bronze}

Paulo Sérgio Pereira Gonçalves ES Alves Martins (Viseu)

Juntamente com estes 3 medalhados, foram também apurados para a fase preparatória das competições internacionais de 2011 os seguintes participantes:

$x$ Carlos César da Fonte Senra Cooperativa DIDÁLVI (Alvito de S. Pedro) x David Naod Berhann Leal da Câmara (Rio de Mouro)

$x$ João António Silva Nunes ES3B Soares Basto (Oliveira de Azeméis)

x João Pedro Batista Gama ES3B de Penafiel

$x$ João Miguel Pimenta Pereira ES3B de D. Inês de Castro (Alcobaça)

$x$ Mariana Isabel Marques ES Leal da Câmara (Rio de Mouro)

\section{$x$ Vasco Figueiredo Batista} ES3B de Carregal do Sal

O Prémio "Melhor Escola", que distingue a instituição com o melhor conjunto de resultados dos seus 3 participantes foi atribuído à ES de $D$. Inês de Castro, de Alcobaça.

\title{
Menção Honrosa na 42a Olimpíada Internacional de Química
}

A equipa portuguesa obteve uma Menção Honrosa na $42^{a}$ Olimpíada Internacional de Química - IChO, realizada em Tóquio, Japão, no passado mês de Julho. O feito foi conseguido pelo Jorge Pedro Martins Nogueiro, finalista da Escola Secundária Emídio Garcia, de Bragança.

A equipa portuguesa que se deslocou ao Japão é ainda constituída pelos alunos Gonçalo Vitorino Bonifácio, da ES José Saramago (Mafra), Marta Cristina Neves Aguiar da ES de Homem Cristo (Aveiro) e Alexandre Faia Carvalho da ES/B3 de Peniche e foi acompanhada pelas docentes do Departamento de Química da Universidade de Aveiro que coordenaram a preparação, Amparo Faustino e Diana Pinto.

Pela primeira vez desde que iniciou a participação na competição (em 2003), a equipa portuguesa teve duas classificações acima dos $50 \%$ e uma Menção Honrosa. De referir que as Olimpíadas Internacionais de Química têm provas de elevado grau de exigência, com um programa de química de grande extensão, e o desempenho dos alunos é não só condicionado pela qualidade do ensino secundário de cada país mas também pelo número de anos de preparação específica. No caso da representação de Portugal, a preparação dos participantes

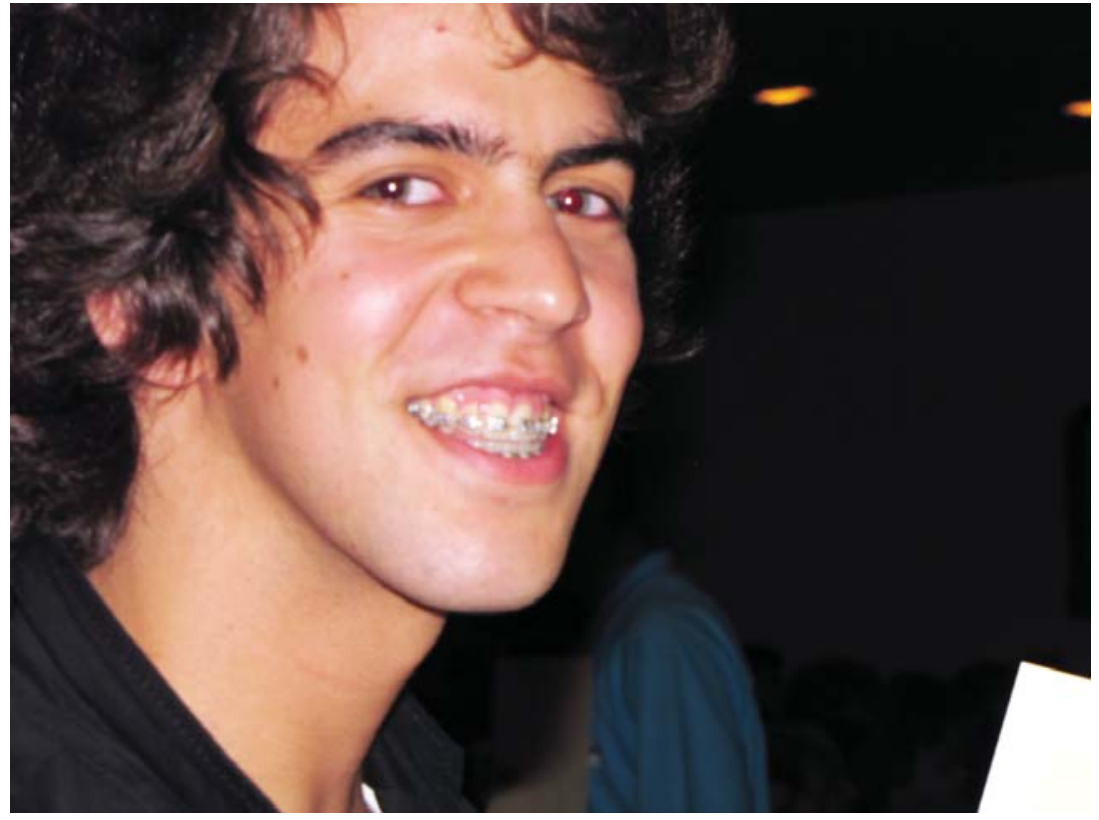

Jorge Nogueiro, Menção Honrosa na $42^{a}$ Olimpíada Internacional de Química

das Olimpíadas Internacionais e das Olimpíadas Ibero-americanas de Química está sedeada no Departamento de Química da Universidade de Aveiro desde 2002 e decorre tipicamente durante as pausas lectivas do ano que antecede a prova e após selecção dos participantes nas Olimpíadas Portuguesas de Química.

As Olimpíadas de Química são uma actividade promovida pela Sociedade Portuguesa de Química (www.spq.pt) com o patrocínio do Ministério da Educação e que visa (i) dinamizar o estudo e ensino da Química nas Escolas Básicas e Secundárias, (ii) proporcionar a aproximação entre as Escolas Básicas e Secundárias e as Universidades, e (iii) despertar o interesse pela Química, cativando vocações para carreiras científico-tecnológicas entre os estudantes.

\section{Vamos enriquecer o miundo da Química Ce Colabore connosco!}

